\title{
The Employee Performance: Recruitment, Training and Job Promotion at PT. Galva Kami Industri
}

\author{
M. Bukhori ${ }^{1}$, Indra Permana \\ Pelita Bangsa University \\ ${ }^{1}$ bukhori@pelitabangsa.ac.id, ${ }^{2}$ indrapermana@pelitabangsa.ac.id
}

\begin{abstract}
Declining employee performance is a problem that occurs at PT.Galva Kami Industri. This is shown because the amount of goods damaged / damaged does not meet the standards made by employees. Declining employee performance is caused by several factors, namely recruitment, training, promotion. This study aims to determine the effect of recruitment, training and promotion of positions on employee performance. The theory used for this research is the management of human resources related to recruitment, training, promotion and employee performance. This type of research is quantitative. The population of the employees of PT. Galva Kami Industri and sampling using slovin formula with a sample of 87 respondents. Data collection includes observation, questionnaire distribution, and literature study where the results will be tested using SPSS22 through validity, reliability, classic assumption, normality and hypothesis testing. The results of the study concluded that the recruitment variable was obtained tcount $2.222>\mathrm{t}$ table 1.989. This shows partially the leadership gaua variables affect employee performance. The partial test of training was obtained tcount $3.258>\mathrm{t}$ table 1.989 . This shows that partially the training variable has an effect on the employee performance variable, while from the partial test of the promotion promotion variable, it is obtained the tcount of $1,271<$ ttable 1,989 . This shows that partially the promotion variable has no effect on employee performance.
\end{abstract}

Keyword: Recruitment, Training, Promotion, Employee Performance

\section{Introduction}

Human Resources is essentially one of the capital and holds the most important role in achieving company goals. Human resources are an important role in determining the success of an organization, all the potential of human resources is very influential on the efforts of the organization in achieving its goals. Companies that have competitive advantages generally have reliable sources to win the competition. One such source is human resources, the competition possessed by human resources makes human resources themselves able to explore the potential and optimize the use of other resources to achieve company profitability

The problem that is being faced by PT. Galva Kami Industri is related to declining employee performance. this is due to lack of knowledge possessed by employees, to improve employee performance requires good management so that the agreed goals can be achieved. Business organizations or companies if they want to survive in a competitive environment, in general must have a number of resources that are relied upon to compete with other companies.

Employee performance can be affected by the recruitment process. The recruitment process carried out by the company can make it easier for companies to find qualified employees at work and can increase employee productivity at work, with the right recruitment 
process the company will get the best employees and can improve the performance of these employees. Based on the results of research Hasibuan (2011: 41) in Andayati (2018) which states recruitment has a partially positive effect on employee performance.

Employee performance can also be influenced by training. Training is one of the efforts in improving the quality of human resources in the world of work. The importance of training to improve competency and maintain competent HR according to Sinambela (2012: 209) in Busro (2018), with the training expected to encourage employee morale, improve employee morale and job satisfaction, increase employee work productivity, increase discipline and reduce levels employee absenteeism, creating a good atmosphere and working relationships. Besides paying attention to training to improve employee performance. The promotion of position also provides an important role for every employee, even becoming a dream that is always expected by employees who will stimulate employee passion at work. Based on the results of research Hasibuan (757:107) in Setiawan (2018) states that there is a significant influence between promotion of employee performance.

Based on observation carried out by the authors of the phenomenon that occurred at PT. Galva Kami Industri is related to the decline in employee performance caused by an inefficient recruitment process that results in employees not working following their expertise. The other phenomenon relates to the lack of training received by employees, causing a lack of ability and skills they have at PT. Galva Kami Industri. This phenomenon occurs in PT. Galva Kami Industri also related to the promotion of positions that are rarely held in the company for employees who have worked long enough. Based on the explanation above, it appears that recruitment, training and promotion can influence employee performance. So in this case the authors are interested in examining The Effect of Recruitment, Training and Job Promotion on the Performance of Employees of PT. Galva Kami Industri.

The hypothesis is a temporary answer to the research problem until proven through the data collected (Arikunto, 2004) based on the theoretical basis above, the research hypothesis is formulated as follows: There is an Effect of Recruitment, Training and Job Promotion on Employee Performance at PT Galva Kami Industri in Cikarang.

\section{Research Methods}

\subsection{Validity Test Analysis Tool}

A validity test is used to measure the validity of a questionnaire in data collection. This validity test is carried out to find out whether the statement items in the questionnaire can express with certainty what was studied. (Arikunto, 2010). Decision-making criteria are: If Rhitung $>$ Rtable then declared valid; If Rhitung $<$ Rtable then declared notvalid.

\subsection{Reliability Test}

Reliability Test is used to test the level of accuracy that is constant or not. Besides, the reliability test is intended to determine the consistency of the measuring instrument in its use. The method used to test the reliability of the questionnaire in this study is to measure reliability with Cronbach's Alpha statistical tests. To find out the questionnaire is reliable, it will be tested the reliability of the questionnaire with the help of the SPSS computer program. According to Ghozali (2009), the calculation of Cronbach's alpha can use the tool to help computer program SPSS for Windows using Alpha models. An instrument is carried out 
reliably if the alpha value is greater than 0,5 .

\subsection{Multiple Linear Regression Analysis}

A method used to process the results of research in order to obtain a conclusion. The data processing method used is Multiple Linear Regression Analysis. To determine the effect of Recruitment $\left(\mathrm{X}_{1}\right)$, Training $\left(\mathrm{X}_{2}\right)$, Job Promotion $\left(\mathrm{X}_{3}\right)$ on Employee Performance $(\mathrm{Y})$. Calculate the Equation of Multiple Regression with the formula:

$$
\mathrm{Y}=\mathrm{a}+\mathrm{b} 1 \mathrm{X} 1+\mathrm{b} 2 \mathrm{X} 2+\mathrm{b} 3 \mathrm{X} 3
$$

$$
\begin{array}{lll}
\mathrm{Y} & =\text { Employee Performance Variable } \mathrm{X}_{1} \quad=\text { Recruitment } \\
\mathrm{X}_{2} & =\text { Training } \\
\mathrm{X}_{3} & =\text { Job Promotion } \\
\mathrm{b}_{1} & =\text { Recruitment Regression Coefficient } \mathrm{b}_{2}=\text { Training Regression Coefficient } \\
\mathrm{b}_{3} & =\text { Job Promotion Regression Coefficient } \mathrm{a}=\text { constant }
\end{array}
$$

\subsection{Hypothesis}

\section{a) Testing t-Test (Partial)}

T-test is a test to determine the significance of the influence of independent variables on the dependent variable individually and assume that the other dependent is constant. The significance of this influence can be estimated by comparing the $t$ table value with the $t$ calculated value. If the value of $t_{\text {count. }}>$ rather than $t_{\text {table }}$ then the independent variable individually affects the dependent variable, conversely if the value of $t_{\text {count }}<$ rather than $t_{\text {table }}$ then the independent variable individually does not affect the dependent variable.

\section{b) F Test (Simultaneous)}

This test is conducted to determine whether all independent variables together can affect the dependent variable. The testing step is to determine the Hypothesis Formulation

\section{c) Coefficient of Determination $\left(\mathbf{R}^{2}\right)$}

The coefficient of determination aims to measure how far the model in explaining the variation of the dependent variable. The value of the coefficient of determination is 0

\section{Results And Discussion}

\subsection{Validity test}

Validity test is used to measure the validity of a questionnaire. The basis for decision a king is to do a significance test by comparing the value of $r$ arithmetic with $r$ tables. For a sample of 87 people, the $r$ table value is 0.213 . Then the results of the analysis are as follows: 
Table 1. Validity test

\begin{tabular}{|c|c|c|c|}
\hline Indicator & $r$ count & r table & Result \\
\hline \multicolumn{4}{|l|}{ Recruitment } \\
\hline P1 & 0,708 & 0,213 & Valid \\
\hline $\mathrm{P} 2$ & 0,760 & 0,213 & Valid \\
\hline P3 & 0,744 & 0,213 & Valid \\
\hline P4 & 0,624 & 0,213 & Valid \\
\hline P5 & 0,756 & 0,213 & Valid \\
\hline \multicolumn{4}{|l|}{ Training } \\
\hline P1 & 0,666 & 0,213 & Valid \\
\hline $\mathrm{P} 2$ & 0,684 & 0,213 & Valid \\
\hline P3 & 0,523 & 0,213 & Valid \\
\hline P4 & 0,784 & 0,213 & Valid \\
\hline P5 & 0,525 & 0,213 & Valid \\
\hline P6 & 0,721 & 0,213 & Valid \\
\hline P7 & 0,469 & 0,213 & Valid \\
\hline P8 & 0,738 & 0,213 & Valid \\
\hline \multicolumn{4}{|l|}{ Job Promotion } \\
\hline P1 & 0,636 & 0,213 & Valid \\
\hline $\mathrm{P} 2$ & 0,678 & 0,213 & Valid \\
\hline P3 & 0,479 & 0,213 & Valid \\
\hline P4 & 0,739 & 0,213 & Valid \\
\hline P5 & 0,582 & 0,213 & Valid \\
\hline P6 & 0,720 & 0,213 & Valid \\
\hline P7 & 0,583 & 0,213 & Valid \\
\hline P8 & 0,687 & 0,213 & Valid \\
\hline \multicolumn{4}{|l|}{ Employee } \\
\hline \multicolumn{4}{|l|}{ Performance } \\
\hline P1 & 0,742 & 0,213 & Valid \\
\hline $\mathrm{P} 2$ & 0,750 & 0,213 & Valid \\
\hline P3 & 0,673 & 0,213 & Valid \\
\hline P4 & 0,601 & 0,213 & Valid \\
\hline P5 & 0,781 & 0,213 & Valid \\
\hline P6 & 0,785 & 0,213 & Valid \\
\hline
\end{tabular}

From table 1 above it can be explained if $r$ count $>r$ table it can be concluded that all statement items in the indicator variable Recruitment (X1), Training (X2) and Job Promotion (X3) are all valid statement items. For the Employee Performance variable (Y), all valid statement items can be known.

\subsection{Reliability Test}

Reliability Tests are used to measure the consistency of variables over time. In the reliability test, a variable is declared reliable if it has a Cronbach alpha value greater than 0.500 (Ghozali, 2009). The reliability test results can be seen from the following table 2:

Table 2. Reliability Test

\begin{tabular}{lccr}
\hline Variable & Cronbach Alpha & Significant & Result \\
\hline Recruitment (X1) & 0,759 & 0,5 & Reliabel \\
Training (X2) & 0,792 & 0,5 & Reliabel \\
Job Promotion (X3) & 0,799 & 0,5 & Reliabel \\
Employee & 0,825 & 0,5 & Reliabel \\
Performance (Y) & & & \\
\hline
\end{tabular}


Based on table 2 above, it can be explained that the Recruitment $\left(\mathrm{X}_{1}\right)$, Training $\left(\mathrm{X}_{2}\right)$ and Job Promotion $\left(\mathrm{X}_{3}\right)$ variables indicate that the Cronbach alpha value is greater than the significant level, so that the results of the reliability test on this variable Recruitment, Training and Job Promotion are reliable. Based on table 2 above it can be explained that the employee performance variable (Y), obtained a Cronbach alpha value of 0.825 with a significance level of 0.5 This indicates that Cronbach alpha is greater than a significant level $(0.825>0.5)$, so that the results of the reliability test on this variable is reliable.

\subsection{Multiple Linear Regression}

To analyze the Effect of Recruitment, Training and Job Promotion of Position on Employee Performance at PT Galva Kami Industri Cikarang, testing and proving the effect are multiple linear regression analysis. The results of the calculation of multiple linear regression with SPSS program version 22.0 from the coefficient table used obtained the following equation:

Table 3. Multiple Linear Regression

\begin{tabular}{|c|c|c|c|c|c|c|}
\hline & \multirow[b]{3}{*}{ Model } & \multicolumn{2}{|r|}{ Coefficients } & \multirow{2}{*}{$\begin{array}{c}\text { A } \\
\text { Standardized } \\
\text { Coefficients }\end{array}$} & \multirow[b]{3}{*}{$\mathrm{t}$} & \multirow[b]{3}{*}{ Sig. } \\
\hline & & & $\begin{array}{l}\text { tandardized } \\
\text { oefficients }\end{array}$ & & & \\
\hline & & $\mathrm{B}$ & Std. Error & Beta & & \\
\hline \multirow[t]{4}{*}{1} & (Constant) & $-2,767$ & 4,858 & &,- 569 &, 571 \\
\hline & Recruitment & ,265 &, 119 & ,213 & 2,226 & 029 \\
\hline & Training & ,425 &, 130 & ,450 & 3,258 & ,002 \\
\hline & Job Promotion &, 182 &, 143 & , 190 & 1,271 & ,207 \\
\hline
\end{tabular}

$\mathrm{Y}=-2,765+0,265 \mathrm{X} 1+0,425 \mathrm{X} 2+0,182 \mathrm{X} 3$

The interpretation of the regression equation above is as follows:

a) A constant value of $-2,765$ means that if the Recruitment, training and promotion variable is 0 , the employee's performance is -2.765 .

b) The beta coefficient value on the Recruitment variable is 0.213 , which means that every change in the recruitment variable $\left(\mathrm{X}_{1}\right)$ by one unit will result in a change in recruitment $\left(\mathrm{X}_{1}\right)$ 0,213 units. Conversely, a decrease in one unit in the recruitment variable $\left(\mathrm{X}_{1}\right)$ will reduce employee performance $(\mathrm{Y})$ by 0.213 with other assumptions are fixed.

c) The beta coefficient value of the training variable is 0.450 , which means that any change in the training variable $\left(\mathrm{X}_{2}\right)$ of one unit will result in a change of training $\left(\mathrm{X}_{2}\right)$ of 0.450 units. Conversely, a decrease in one unit in the training variable $\left(\mathrm{X}_{2}\right)$ will reduce employee performance by 0.450 with other assumptions are fixed.

d) The beta coefficient value on the promotion variable is 0.190 which means that every change in Job Promotion variable $\left(\mathrm{X}_{3}\right)$ is one unit will result in a change in Job Promotion $\left(\mathrm{X}_{3}\right)$ of 0.190 units. Conversely, a decrease in one unit in the Job promotion variable $\left(\mathrm{X}_{3}\right)$ will reduce employee performance by 0.190 with other assumptions are fixed. 


\subsection{Hypothesis t-test}

The $t$ test is intended whether the variable Recruitment and Job Promotion has an influence on Employee Performance at PT Galva Kami Industri Cikarang. To simplify this test, the authors use SPSS 22.0 which results are as follows: The indication is that if $t$ arithmetic $>$ from $t$ table at the level of significance, the independent variable concerned is partially considered to have a significant effect on the dependent variable, and vice versa, if $t$ arithmetic $<$ from $t$ table then the independent variable concerned is considered to have no significant effect on the dependent variable.

\section{a) Recruitment $\left(\mathbf{X}_{1}\right)$}

In the recruitment variable, the value of tcount is 2.222 while ttable is 1.989 , thus tcount $=$ $2.222>$ ttable $=1.989$ and the significance value is $0.029(\mathrm{sig}<0.05)$. Based on the analysis, the hypothesis which states "there is a partially positive effect between the Recruitment free variable $\left(\mathrm{X}_{1}\right)$ on the employee performance dependent variable at PT. Galva Kami Industri" is declared accepted.

\section{b) Training $\left(\mathbf{X}_{2}\right)$}

In the training variable, the value of tcount is 3.258 while ttable is 1.989 , thus $t$ arithmetic $=3.258>\mathrm{t}$ table $=1.989$ and the significance value is $0.002(\mathrm{sig}<0.05)$. Based on the analysis, the hypothesis which states "there is a partially positive influence between the independent variables of Training $\left(\mathrm{X}_{2}\right)$ on the dependent variable Employee Performance at PT. Galva Kami Industri" is declared accepted.

\section{c) Job Promotion $\left(\mathbf{X}_{3}\right)$}

In the promotion variable, it is obtained tcount 1,271 while ttable is 1,989 so $t$ count $=$ $1,271<\mathrm{t}$ table $=1,989$ and significance value 0,207 $(\mathrm{sig}>0,05)$. Based on the analysis, the hypothesis which states "there is a partially positive effect between the independent variable Job Promotion $\left(\mathrm{X}_{3}\right)$ on the dependent variable Employee Performance at PT. Galva Kami Industri" was declared rejected.

\subsection{Determination Coefficient Test Results (Adjusted R2)}

Determination analysis is used to determine the effect of the independent variables together on the dependent variable. The results of the determination analysis can be seen in the following table:

Table 4. Model Summary

\begin{tabular}{ccc}
\hline R Square & Adjusted R Square & Std. Error of the Estimate \\
\hline 606 &, 592 & 3,757 \\
\hline
\end{tabular}

a. Predictors: (Constant), Job Promotion (X3), Recruitment (X1), Training (X2)

a. Dependent Variable: Job Promotion (Y)

From the results of this study, the coefficient of Adjusted $\mathrm{R}^{2}$ determination value was 
$0.592 \%$. This means that the influence of the variable Recruitment $\left(\mathrm{X}_{1}\right)$ Training $\left(\mathrm{X}_{2}\right)$ Job Promotion $\left(\mathrm{X}_{3}\right)$ together affect the Employee Performance variable by $59.2 \%$ while the remaining $41.8 \%$ is influenced by other variables not included in this study.

\section{Conclusion}

a) In the recruitment variable tcount is 2.222 while ttable is 1.989 , thus $t$ arithmetic $=$ $2.222>\mathrm{t}$ table $=1.989$ and significance value $0.029(\mathrm{sig}<0.05)$, so it can be concluded that there is a positive and significant influence between the Recruitment variables on Employee Performance variable at PT.Galva Kami Industri.

b) In the recruitment variable tcount obtained 3.258 while ttable is 1.989 , thus $t$ arithmetic $=3.258>\mathrm{t}$ table $=1.989$ and significance value $0.002(\mathrm{sig}<0.05)$, so it can be concluded that there is a positive and significant influence between the training variables on Employee Performance variable at PT.Galva Kami Industri.

c) In the promotion promotion variable, the tcount is 1,271 while the ttable is 1,989 , thus $t$ arithmetic $=1,271<\mathrm{t}$ table $=1,989$ and the significance value is 0.207 ( $\mathrm{sig}>0.05)$, so it can be concluded that there is a positive influence between the independent variable Position Promotion towards the dependent variable PT. Galva Kami Industri, however, there is no significant influence of promotion variable on the performance of employees of PT.Galva Kami Industri.

\section{Acknowledgements}

I cannot express enough thanks to my committee for their continued support and encouragement: Prof. Dr. Wiwiek Rabiatul Adawiyah, my lecturer of Program Doktor Ilmu Ekonomi jenderal Soedirman University ; Dr. Budiaji; and Dr. E. Suharno. I offer my sincere appreciation for the learning opportunities provided by my study. Finally, to my caring, loving, and supportive all of my friends at Pelita Bangsa University: my deepest gratitude. All of Your encouragement when the times got rough are much appreciated and duly noted. It was a great comfort and relief to know that you were willing to provide management of our household activities while I completed my work. My heartfelt thanks.

\section{References}

[1] Arif, Muhamad. (2017). Analisis rekrutmen dan penempatan kerja terhadap kinerja karyawan pada karyawan Hotel Oase Pekan Baru, terbit di jurnal Al-Hikmah : Volume 15, Nomor 1, April 2018.

[2] Bintarti, Surya September, 2015. Metodologi Penelitian Ekonomi Manajemen. Jakarta :Mitra Wacana Media.

[3] Busro, Muhamad April, 2018. Teori-teori Manajemen Sumber Daya Manusia. Jakarta: Prenamedia Grup.

[4] Endayani, Fatmasari, Hamid Djamhur, Djudi Mochamad,2015 Pengaruh pelatihan kerja dan kemampuan kerja terhadap kinerja karyawan pada PT. BPRS Bumi Rinjani Kepanjen, terbit di jurnal Administrasi Bisnis (JAB) : Volume 25, Nomor 1, Agustus 2015 
[5] Fathin, Amirah, Ningrum Lestari, Abas Ahmad Junaedi, 2018.The Influence of Recruitment Process on Performace and Job Satisfaction at The Dharmawangsa Jakarta, terbit di jurnal Tourism Research Journal : Volume 2, Nomor 1,2018.

[6] Hasanah, Im'roatul, 2017. Pengaruh rekrutmen, pelatihan dan penempatan kerja terhadap kinerja karyawan pada RSU Haji Surabaya, terbit di jurnal Ilmu dan Riset Manajemen : Volume 8, Nomor 6, Agustus 2017.

[7] Mandagi, Aprilia,2017 Pengaruh promosi jabatan dan rotasi pekerjaan terhadap kinerja pegawai dinas lingkungan hidup kota Manado, terbit dijurnal EMBA : Volume 5, Nomor 3, 2017.

[8] Pratama, Aan Rio, Qomari Nurul, Negoro Bramastyo Kusumo,2017 Pengaruh rekrutmen, penempatan dan pelatihan kerja terhadap kinerja karyawan PT. Unilever Indonesia,Tbk, terbit dijurnal Manajemen Branchmark : Volume 3, Issue 3, 2017.

[9] Priyatno, Dwi, 2016. SPSS Hand Book Analisa Data Olah Data \& Penyelesaian Kasus-kasus Statistik. Yogyakarta : MediaKom.

[10] Rahayu, Suharni, 2017. Pengaruh promosi jabatan tehadap kinerja karyawan PT.Metalindo, terbit dijurnal KREATIF Pemasaran, Sumber daya manusia dan Keuangan : Volume 5, Nomor 1, Oktober 2017.

[11] Saifalislam, Osman, Alkudah, 2014 Human Resource Management Pratices : Influences of recruitment and selection, and training development on the prganizatonal performance pf the Jordanian Publik University, terbit di jurnal Journal of Business and Management : Volume 16, Nomor 5, Mei 2014.

[12] Setiawan, Abdi, 2018 Pengaruh promosi jabatan dan lingkungan kerja terhadap kinerja karyawan di lingkungan Universitas pembangunan panca budi Medan, terbit dijurnal Akuntasi, Bisnis \& Publik, Volume 8, Nomor 2, 2018.

[13] Sunarsi, Denok, 2016. Pengaruh rekrutmen, seleksi dan pelatihan terhadap produktivitas karyawan, terbit dijurnal KREATIF : Volume 6, Nomor 1, Januari 2016.

[14] Wattiheluw, Afriati, 2017. Pengaruh pemberdayaan dan pelatihan terhadap kinerja pegawai usaha mikro kecil dan menengah (studi kasus UKM kota Ambon), terbit dijurnal Manis : Volume 6, Nomor 1, 2017. 